Témoigner Témoigner. Entre histoire et mémoire

Getuigen Revue pluridisciplinaire de la Fondation Auschwitz

$122 \mid 2016$

Révisionisme et négationisme

\title{
The Imitation Game: wiskundeknobbel in de schaduw
}

The Imitation Game : Le matheux de l'ombre

\section{Erik Machielsen}

Traducteur : Gorik de Henau

\section{(2) OpenEdition}

\section{Journals}

Édition électronique

URL : https://journals.openedition.org/temoigner/4085

DOI : $10.4000 /$ temoigner.4085

ISSN : 2506-6390

Éditeur :

Éditions du Centre d'études et de documentation Mémoire d'Auschwitz, Éditions Kimé

Édition imprimée

Date de publication : 2 mai 2016

Pagination : 20-23

ISSN : 2031-4183

Référence électronique

Erik Machielsen, «The Imitation Game: wiskundeknobbel in de schaduw», Témoigner. Entre histoire et mémoire [Online], 122 | 2016, Online op 30 septembre 2021, geraadpleegd op 04 janvier 2022. URL: http://journals.openedition.org/temoigner/4085 ; DOI: https://doi.org/10.4000/temoigner.4085 


\section{THE IMITATION GAME: WISKUNDEKNOBBEL IN DE SCHADUW}

FILM Tegenwoordig kan film via zijn beeldende kracht en narratieve beheersing - zij het vaak ten koste van een zeker academisme, het product van de al te talrijke filmscholen - de toeschouwer iets bijbrengen en tegelijk postvatten in de hoogste regionen van de box office. Denk maar aan Christopher Nolan en diens visie op Batman of aan Interstellar, zijn intergalactische psychothriller.

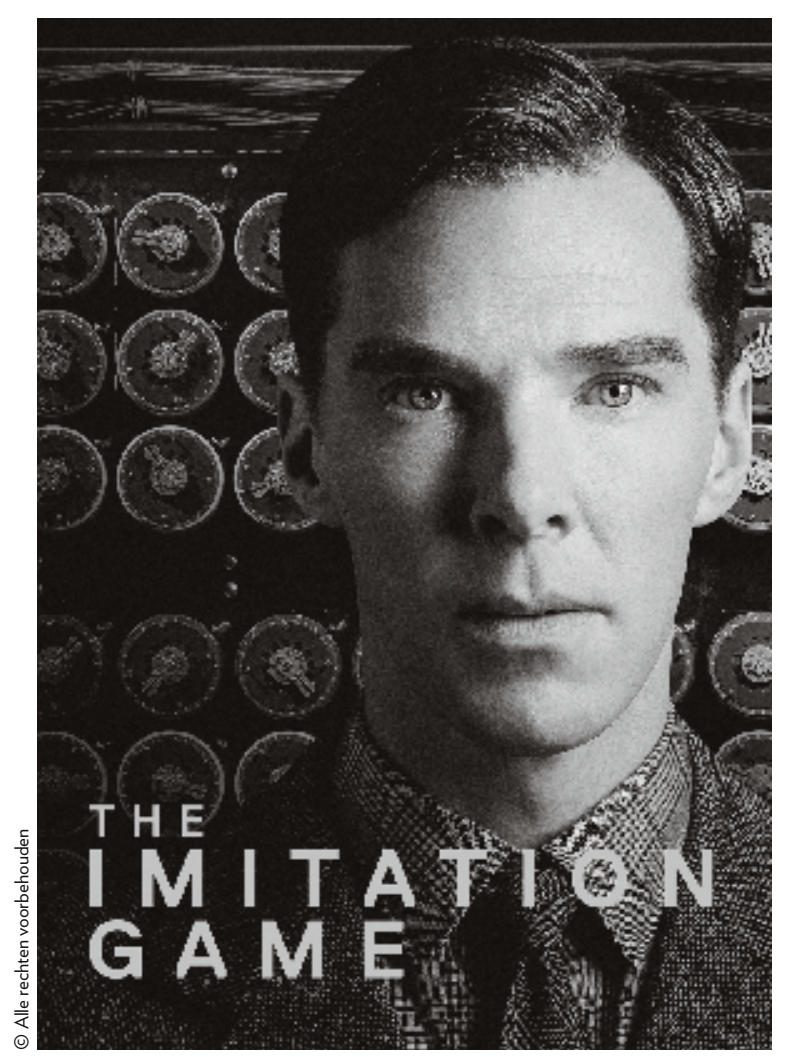

The Imitation Game kwam uit in januari 2015 en won tijdens hetzelfde jaar de Oscar voor de beste film. De film is een voorbeeld van de heilzame benadering waarmee de zevende kunst aanspraak kan maken op de grote $K$ van kunst-met-eenhoofdletter.
I n de als een thriller geconstrueerde film wordt het waargebeurde verhaal verteld van Alan Turing, door Time Magazine verkozen tot een van de honderd meest invloedrijke figuren van de twintigste eeuw. Deze Britse wiskundige en cijfergenie is velen waarschijnlijk volslagen onbekend. Toch heeft hij een doorslaggevend rol gespeeld in het verloop van de geschiedenis van de twintigste eeuw. Het feit dat u dit artikel in alle vrijheid en in leven kan lezen is daarvan een sluitend bewijs. Dit voorrecht is helaas anderen niet gegund geweest, want Turing liet hen doelbewust ten prooi aan de handlangers van het Derde Rijk - het algemeen belang primeert nu eenmaal op het privébelang. Want ja, dit verhaal speelt zich af tijdens de Tweede Wereldoorlog.

\section{1}

Manchester, Alan Turing wacht in zijn cel en maakt zich op om zijn levensverhaal te vertellen aan een rechercheur die maar geen hoogte van hem kan krijgen en vastbesloten is meer te weten te komen over zijn verleden. Na een inbraak wil die rechercheur documenten over Turing consulteren, maar hij krijgt geen toegang tot diens militaire dossier, dat als uiterst geheim is geclassificeerd. Wanneer hij het uiteindelijk toch te pakken krijgt, blijkt het dossier leeg te zijn. Waarom? 


\section{FLASHBACK, 1939}

Turing komt aan in Bletchley Park, op negentig kilometer van Londen. Op die plek bevindt zich een fabriek waar radio's worden gemaakt, maar in werkelijkheid gaat het om het hoofdkwartier van de Britse inlichtingendienst, waar nazicommunicatie wordt onderschept en geanalyseerd. Turing werd geselecteerd voor een team dat aan een uiterst geheim project werkt; ze moeten de Duitse boodschappen ontcijferen die worden gecodeerd door Enigma, een enorm geavanceerde codeermachine. Voor Turing, die een groot liefhebber is van denkspelletjes, is het eindelijk een puzzel op niveau. Ondanks de reserves van zijn onmiddellijke overste krijgt hij steun van Winston Churchill en hij wordt aangesteld als leider van een team. De taak van het team bestaat eruit de interne boodschappen te kraken waarin de dag en plaats van de Duitse legeraanvallen worden meegedeeld. Turing vervolledigt zijn team met een nieuwe knappe kop, die hij aanwerft zoals hij destijds zelf door de inlichtingendiensten is aangeworven. Via kruiswoordraadsels in de krant selecteert hij een eerste reeks kandidaten en laat hen vervolgens om ter snelst een ander raadsel oplossen. Joan Clarke doet er 5 minuten 38 seconden over, terwijl Turing zelf 8 minuten nodig had.

Maar Turing blijkt arrogant en eist zijn eigen bureau. Dankzij de geduldige en rustige Joan Clarke leert hij dat je van mensen meer gedaan krijgt door hun liefde te geven dan door hen onder de knoet te houden. De uitdaging is immens: elk dag wijzigen de Duitsers de versleutelcode van Enigma, één uit wel 159 miljard mogelijkheden. Op die manier kunnen mensen onmogelijk op een paar uur tijd de sleutel kraken. Willen ze Duitsland verslaan, dan moeten ze dus ook een gevecht tegen de tijd leveren. Volgens Turing kan de machine van de vijand alleen door een andere machine worden verslaan. Daartoe moeten ze een numeriek brein ontwerpen dat in staat is de gestelde problemen op te lossen. Het programma ziet het licht en dus geldt Turing als een van de uitvinders van de computer. Het prille concept daarvan was bedacht door een andere Brit, namelijk Charles Babbage (1791-1871), die een eeuw eerder de eerste rekenmachine had uitgedokterd.

\section{CHRISTOPHER, MON AMOUR}

We weten hoe de film zal eindigen en het gaat er niet zozeer om te vernemen of Turing zal slagen, maar hoe. Daartoe keren we terug naar zijn universiteitsja- ren in Cambridge, meer bepaald naar zijn ontmoeting met Christopher Morcom, de enige student die hem affectie toont en hem in bescherming neemt tegen de pesterijen van de andere studenten. Turing beweert intelligent te zijn, maar Morcon antwoordt vinnig van niet; hij is alleen anders. Uit het vervolg leren we dat ze allebei gelijk hadden. Christopher brengt hem de beginselen van de cryptografie bij en besmet hem met het virus waarmee hij zijn opzoekingen kan aanvangen en, na de onverwachte dood van Morcom, definitief voortzetten. Turing tracht de belofte van zijn makker waar te maken door hem te doen voortleven in zijn levenswerk, namelijk een machine die problemen kan oplossen waar logaritmen niet tegenop kunnen. Hij geeft ze de naam Christopher mee.

\section{VAN HET WAARHEIDSGETROUWE NAAR HET}

\section{'NIET HELEMAAL CORRECTE'}

Dat laatste is een verdraaiing van de waarheid, want de machine heette in werkelijkheid Victory. De film zit vol andere onjuistheden en fictieve toevoegingen. Alan Turing wordt beschreven als een arrogant en autoritair figuur. We zien hoe hij wordt gesard op school en dat hij zich hooghartig opstelt tegenover zijn medewerkers en meerderen. Maar die interpretatie wordt weerlegd door getuigenissen uit zijn omgeving. Daaruit concluderen we dat een en ander deel uitmaakt van de artistieke vrijheid van de regisseur. Om het verhaal te vereenvoudigen en in te werken op het gemoed van de toeschouwer beklemtoont hij het beeld van een wonderkind dat alleen staat met zijn kennis en zekerheden. Een houding die eigen is aan heel wat genieën die op een haar na autistisch zijn; bewust als ze zich zijn van de absurditeit van de hen omringende wereld trekken ze zich terug in een ivoren toren om zich tegen die wereld te beschermen. Zo ontstaat de neiging om het succes van de onderneming alleen aan Turing toe te schrijven, terwijl die tijdens zijn leven nooit het belang van zijn team ontkende en het zelfs prees.

Bovendien verbeterde hij alleen een door de Polen ontworpen machine. Die laatsten beschikten over een exemplaar van Enigma en waren al begonnen met het te analyseren; ze zochten een manier om de sleutel te kraken waarmee de boodschappen van het Heer (landmacht) en de Luftwaffe (luchtmacht) werden versleuteld. Maar in 1940 maakten de Duitsers de werking van Enigma ingewikkelder, waardoor de Polen zich verplicht zagen om van voren af aan te beginnen. 
-. Bovendien ontcijferde Turings machine alleen maar boodschappen van de luchtmacht, en niet van onderzeeërs zoals in de film wordt beweerd. De scène waarin het team besluit geen gebruik te maken van de eerste ontcijferde boodschap - wat het leven kost van de broer van een teamlid, die zich op een van de bedreigde schepen bevindt - is uit de lucht gegrepen, want het bewuste teamlid had geen broer. Maar uit die passage blijkt het dilemma: als een geplande aanval telkens door de geallieerden wordt voorzien, dan zullen de Duitsers dat snel doorhebben en Enigma aanpassen. Turing lost dit op door uit te gaan van statistieken waarbij bepaalde inlichtingen worden genegeerd, wat steeds ten koste gaat van een reeks levens die worden opgeofferd.

We zitten in de ban van het verhaal en de vertolkingen. Daardoor hebben we geen last van die zwakke punten, die bij een tweede visie aan het licht komen. Dan merken we ook de verwijzingen naar episodes uit Turings leven die niet worden uitgediept - het joggen is een zinspeling op het feit dat hij ook een sportman was, maar dat moest je eerst wel weten - en naar de manier waarop hij sterft. Op 7 juni 1954 bijt hij, net als Sneeuwwitje in de film van Walt Disney (waar hij dol op was), in een in cyanide gedompelde appel. Een appel met een hap eruit ... Ga je dan niet denken aan een bepaald logo?

Nog een onjuistheid is dat Joan niet werd aangeworven door Turing, maar door Gordon Welchman, haar universitaire supervisor aan de universiteit van Cambridge. Die wiskundige maakte trouwens deel uit van het team, maar ontbreekt in de film. En daar blijft het niet bij, want Turing richtte zich niet in zijn eentje tot Churchill, maar samen met drie andere teamleden. Commandant Alastair Denniston (een rol van Charles Dance of nog Tywin Lannister, heer van Casterly Rock in de televisiereeks Game of Thrones) komt dan weer over als een weinig sympathiek personage. Opnieuw een overdrijving; door er een 'booswicht' van te maken wordt een confrontatie gecreëerd, wat de psychologische werking van de film versterkt.

In de film wordt Turing ervan verdacht een Sovjetspion te zijn, nog een verdraaiing van de werkelijkheid. Ten slotte was hij inderdaad het slachtoffer van een inbraak. Maar uit het onderzoek bleek dat de dader een van zijn minnaars was, wat betekende dat Turing homoseksueel was - een vaststelling die hij zonder problemen erkende. Want zelfs al had hij er nooit mee te koop gelopen, hij had het ook nooit verborgen

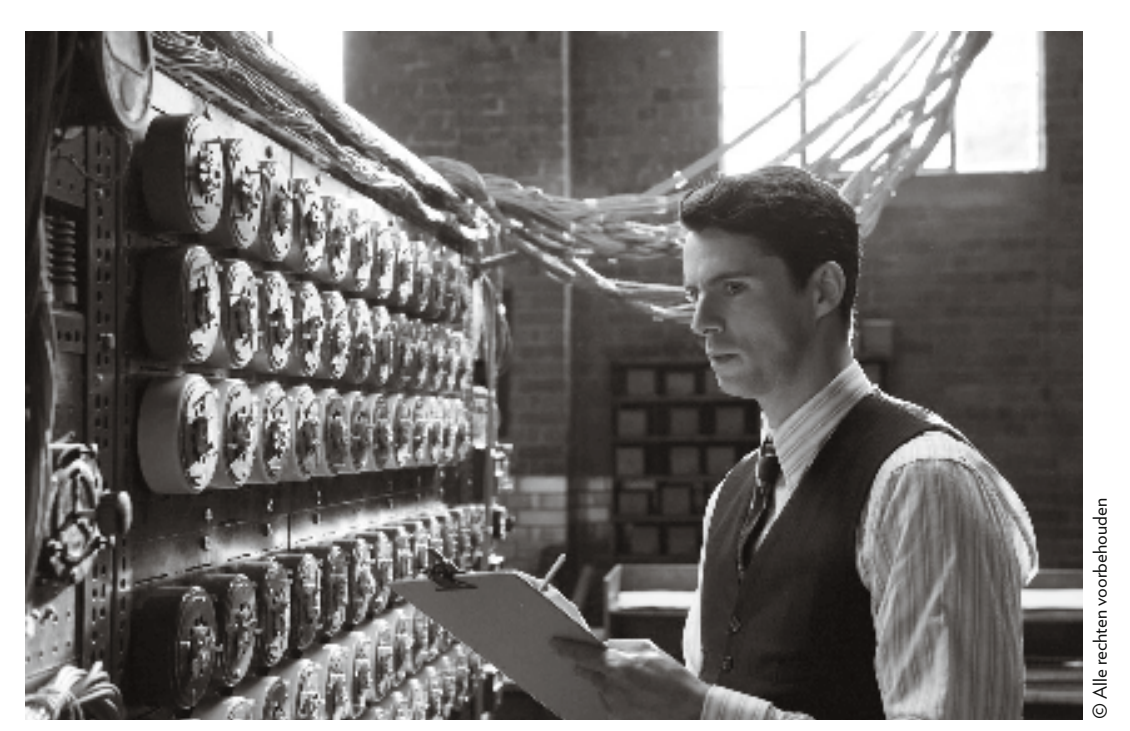

gehouden. Je moet wel weten dat die seksuele voorkeur in het puriteinse Engeland van de jaren 1950, meer dan een halve eeuw na het proces tegen Oscar Wilde, nog altijd als een misdaad gold. Hij werd berecht en veroordeeld, waarna hij door chemische castratie tot zelfmoord werd gedreven. Maar ook nu weer staat er niets onomstotelijk vast, want veeleer dan om bewezen feiten gaat het om gevolgtrekkingen.

\section{SCHOOLS MAAR DOELTREFFEND}

De regie is beheerst, maar daarom niet minder schools. Het is een mooi werkstuk, maar Morten Tyldum komt er niet meteen uit naar voren als een bijzonder regisseur. De montagesequenties (oorlogsbeelden, vliegtuigsquadrons) zijn vrij ‘cheap' in ver- 
gelijking met de realistische scènes binnenskamers. Het cliché van de vernuftige adolescent die wordt gepest aan de universiteit en zich ontpopt tot een hooghartig, cynisch, arrogant, minachtend en door zijn kennis geremd genie wordt zodanig beklemtoond dat het bij momenten karikaturaal wordt. Ook het hele technische aspect is spoorloos verdwenen. We zien Turing wel plannen tekenen, spoelen bouwen enzovoort. Opeens is de machine er, we zien overal radertjes zonder echt te begrijpen waar ze precies toe dienen, waarom het

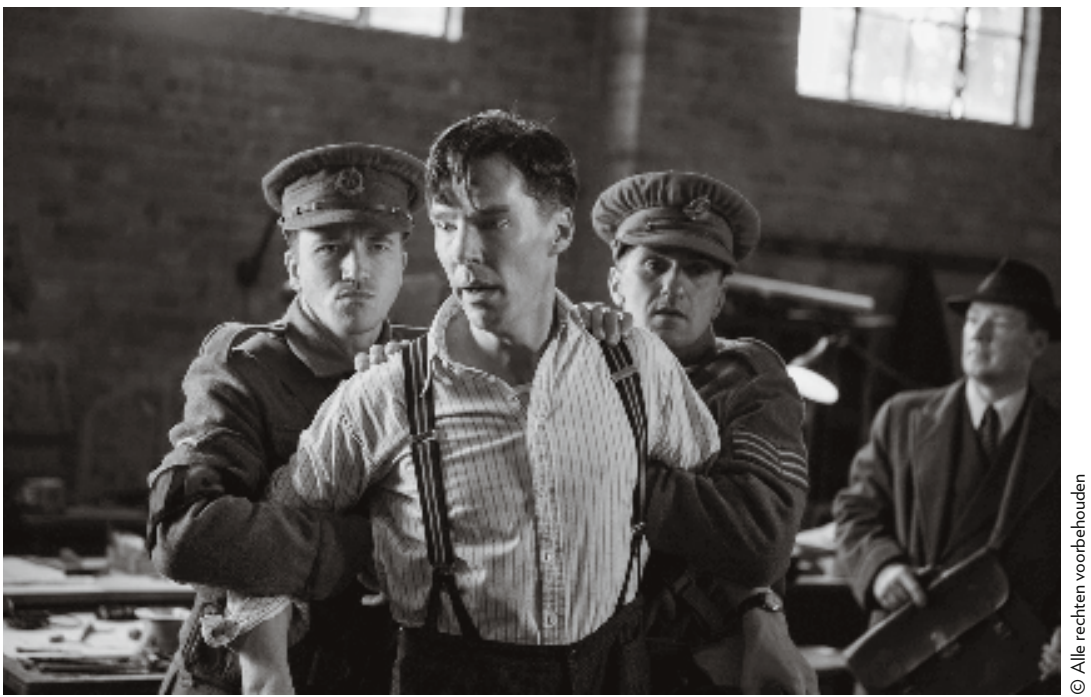
allemaal zoveel plaats inneemt. We bedenken dat alle conflicten in zijn innerlijk niets aan kracht zouden inboeten als ze naar een theaterpodium werden overgeplaatst, wel integendeel. Tot slot is er de titel van de film, een verwijzing naar een test die Turing beschreef in het artikel Computing Machinery and Intelligence, in 1950 verschenen in het universitaire tijdschrift Mind, dus na de gebeurtenissen in de film. Het gaat om een spel waarbij iemand via een toetsenbord vragen moet stellen aan twee gesprekspartners en afgaand op de antwoorden - die hij via een computerterminal krijgt moet bepalen wie een machine is en wie een man (of vrouw). Turing legt het uit tijdens een (ook weer) fictieve sequentie waarin hij zijn hart uitstort bij de rechercheur die hem komt ondervragen.

Door die romantisering van de werkelijkheid wordt film niet minder sterk. En daar zit de vertolking van alle acteurs zonder uitzondering voor veel tussen. Benedict Cumberbatch (in Engeland bekend vanwege zijn recente vertolking van Sherlock Holmes in een televisieserie) is vorstelijk, dubbelzinnig en charismatisch. En wat voor een stem! Na Pride and Prejudice bewijst Keira Knightley ondubbelzinnig dat ze meer is dan een pin-up in blockbusters als Pirates of the Caribbean, waarmee ze bekend werd. Hier toont ze dat ze echt kan acteren en dat haar Oscarnominatie ruimschoots verdiend is. De beelden zijn esthetisch en afgelikt, maar doen geen afbreuk aan de geloofwaardigheid van de gebeurtenissen.

Niet alleen schilders (Van Gogh, Modigliani) oogsten postume roem, het overkomt ook andere figuren met een meer dan gemiddelde intelligentie. Alan Turing had een talent voor cijfers, hij was voorbestemd om te rekenen, het zat hem in het bloed. Zoals sommigen muziek ademen haalde hij zijn zuurstof uit getallen en raadsels. Hij ging er zo sterk in op dat hij de gevolgen van zijn vasthoudendheid niet kon overzien, een beetje zoals dokter Frankenstein. Robert Oppenheimer, Albert Einstein, Bernard Benson (de wetenschapper die raketten hielp bouwen) kenden hetzelfde probleem.

Hij stierf in 1954 op 41-jarige leeftijd. Het aantal levens dat Alan Turing en zijn team redden, wordt op veertien miljoen geschat, waardoor de oorlog met twee jaar werd ingekort. Turing werd postuum in ere hersteld, 57 jaar nadat hij door het Britse rijk was vernederd en veroordeeld. Eerst bood Gordon Brown, de toenmalige eerste minister, hem excuses van staatswege aan en vier jaar later, in 2013, verleende koningin Elizabeth II hem gratie.

Erik Machielsen Vertaling: Gorik de Henau

\section{Meer zeten}

The Imitation Game van Morten Tyldum (2014). Met Benedict Cumberbatch (Alan Turing), Keira Knightley (Joan Clarke), e.a. - 119 minuten. 